\title{
EVALUASI IMPLEMENTASI KEBIJAKAN \\ STANDAR SARANA DAN PRASARANA LABORATORIUM FISIKA SMA NEGERI 2 KOTA TANGERANG SELATAN
}

\begin{abstract}
Waramatias $^{1}$
Abstract: The objective of this research was to evaluate (1) compliance of physics laboratory building requirement and conditions with standard and (2) fulfillment of physics laboratory furniture and practicum equipments at Public Secondary School No. 2 Kota Tangerang Selatan. The method used in the research was qualitative descriptive method with Provus's discrepancy evaluation model (DEM). The data were collected through observation, interview, and document study. Data analysis and interpretation show that the laboratory building (1) did not have a full accordance with safety, healthy, comfort, access easiness, and size and room adequacy tandards in input, process, and output components, and (2) did not fully fulfill types and quantity of furniture, materials and basic measurement tools, practicum kits, educational media, and other equipments in input, process, and output components. The findings lead to recommendation that SMAN 2 Kota Tangerang Selatan should equip its physics laboratory building to meet requirements and conditions in effect and should fulfill its physics laboratory furniture and practicum equipment set in the standard.
\end{abstract}

Keywords: policy evaluation implementation, physics building laboratory requirement and conditions, physics laboratory furniture and practicum equipments.

\section{PENDAHULUAN}

Pasal 2 Undang-Undang Sistem Pendidikan Nasional No. 20/2003 mengatakan bahwa Pendidikan nasional berdasarkan Pancasila dan Undang-Undang Dasar Negara Republik Indonesia Tahun 1945. Pasal 3 UU ini menjelaskan fungsi pendidikan, yaitu mengembangkan kemampuan dan membentuk watak serta peradaban bangsa yang bermartabat dalam rangka mencerdaskan kehidupan bangsa, bertujuan untuk mengembangkan potensi peserta didik agar menjadi manusia yang beriman dan bertaqwa kepada Tuhan yang Maha Esa, berakhlak mulia, sehat jasmani, berilmu, cakap, kreatif, mandiri, dan menjadi warga negara yang demokratis serta bertanggung jawab.

Untuk mengemban fungsi tersebut pemerintah menyelenggarakan suatu sistem pendidikan nasional dengan menetapkan standar yang tertuang di dalam Pasal 35 Undang-undang Nomor 20/2003. Ayat (1) pasal ini menyatakan bahwa standar nasional pendidikan terdiri atas standar isi, proses, kompetensi lulusan, tenaga kependidikan, sarana dan prasarana, pengelolaan, pembiayaan, dan penilaian pendidikan yang harus ditingkatkan secara berencana dan berkala. Selanjutnya pasal 45 ayat (1) menyatakan bahwa setiap satuan pendidikan formal dan nonformal menyediakan sarana dan prasarana yang memenuhi keperluan pendidikan sesuai dengan pertumbuhan dan perkembangan potensi fisik, kecerdasan intelektual, sosial, emosional, dan kejiwaan peserta didik.

Pasal 42 (1) PP No. 19/2005 menyatakan bahwa setiap satuan pendidikan wajib memiliki sarana dan prasarana yang meluputi perabot, peralatan pendidikan, media pendidikan, buku dan sumber belajar lainnya, bahan habis pakai, serta perlengkapan lain yang diperlukan untuk menunjang proses pembelajaran yang teratur dan berkelanjutan. Ayat ini dijabarkan melalui Permendiknas No. 24/2007 tentang Standar

\footnotetext{
${ }^{1}$ Kasi Sarana Prasarana Kemendikbud
} 
Sarana dan Prasarana Sekolah Menengah Atas. Kriteria minimum standar sarana dan prasarana pendidikan yang diatur dalam Permendiknas ini menyatakan bahwa sebuah Sekolah Menengah Atas (SMA/MA) sekurang-kurangnya memiliki prasarana sebagai berikut: (1) ruang kelas; (2) ruang perpustakaan; (3) ruang laboratorium biologi; (4) ruang laboratorium fisika; (5) ruang laboratorium kimia; (6) ruang laboratorium komputer; (7) ruang laboratorium bahasa; (8) ruang pimpinan; (9) ruang guru; (10) ruang tata usaha; (11) ruang beribadah; (12) ruang konseling; (13) ruang UKS; (14) ruang OSIS; (15) jamban; (16) gudang; (17) sirkulasi; dan (18) tempat bermain.

Terkait dengan keadaan ruang laboratorium Fisika SMAN 2 Tangerang Selatan dalam pelaksanaan pembangunan dan proses pengadaan peralatan laboratorium tersebut, sangat dimungkinkan terjadi kesenjangan antara kondisi di sekolah dengan kriteria minimum yang disyaratkan di dalam standar sarana dan prasarana sekolah menengah atas (Permendiknas No. 24 Tahun 2007), khususnya aspek penerapan persyaratan dan ketentuan bangunan dan aspek keterpenuhan jenis dan jumlah peralatan laboratorium Fisika.

\section{Kebijakan Publik}

Torjman (2005:2-3) memberikan empat kategori kebijakan yaitu kebijakan substantif dan administratif, kebijakan vertikal dan horisontal, kebijakan reaktif dan proaktif, serta kebijakan saat ini dan masa depan. Kebijakan substantif dan administratif berhubungan dengan program yang mengatur aspek-aspek mendasar pekerjaan komunitas misalnya inisiatif pembukaan lapangan kerja, layanan kesehatan, dan berfokus pada prosedur-prosedur administratif serta pengumpulan informasi statistik tentang lingkungan. Kebijakan yang bersifat horisontal adalah kebijakan yang dikembangkan di dalam organisasi yang bertanggung jawab terhadap implementasinya dan oleh dua atau lebih organisasi dimana masing-masing memiliki kemampuan atau memiliki kewenangan untuk menangani satu dimensi dari situasi yang ada. Kebijakan juga bisa reaktif dan proaktif. Kebijakan reaktif adalah kebijakan yang umumnya dipahami oleh sebagian besar orang karena muncul sebagai tanggapan terhadap kepedulian atau krisis yang harus ditangani-gawat darurat wabah penyakit dan bencana lingkungan adalah dua contohnya. Kebijakan proaktif, sebaliknya, diperkenalkan dan dicapai melalui pilihan yang disengaja. Kategori yang terakhir, kebijakan saat ini adalah kebijakan yang sedang berada di dalam agenda publik, dan kebijakan masa depan adalah kebijakan yang belum menjadi agenda masyarakat.

Moestopadidjaja (2002:2) mengatakan bahwa kebijakan publik adalah suatu keputusan untuk mengatasi permasalahan yang muncul dalam suatu kegiatan tertentu yang dilakukan oleh instansi pemerintah dalam rangka penyelenggaraan pemerintahan. Sedangkan menurut Wadi D. Hadad (1995:18) kebijakan publik adalah "an explicit or implicit single decision or group of decisions which may set out directives for guiding future decisions, initiate or retard action, or guide implementation of previous decisions." Smith dan Larimer (2009:4-5) dengan mengutip Birkland, mengatakan bahwa kebijakan publik mencakup proses membuat pilihan-pilihan dan keluaran-keluaran atau tindakantindakan dari keputusan-keputusan tertentu; apa yang membuat kebijakan publik menjadi bersifat "publik" adalah karena pilihan-pilihan atau tindakan-tindakan ini didukung oleh kekuasaan pemerintah untuk memaksa; dan bahwa di bagian inti dari kebijakan publik adalah respons terhadap persoalan yang dihadapi atau diantisipasi

Dari paparan di atas dapat disintesiskan bahwa kebijakan publik adalah keputusan dan tindakan yang diambil oleh pemerintah untuk bereaksi terhadap sebuah 
persoalan publik saat ini atau mengantisipasi persoalan yang akan muncul di masa depan di mana hasilnya adalah untuk kepentingan bersama, dan pemerintah dapat menggunakan kekuatan memaksa untuk melaksanakan kebijakan yang dipilih.

\section{Implementasi Kebijakan Publik}

Implementasi kebijakan merupakan bagian dari siklus proses kebijakan. William N. Dunn (2005:7) misalnya, menggambarkan proses pembuatan kebijakan sebagai serangkaian tahapan yang saling terkait, yaitu: (a) penyusunan agenda, (b) formulasi kebijakan, (c) adopsi kebijakan, (d) implementasi kebijakan, dan (e) penilaian kebijakan. Serupa dengan Dunn, Jann dan Wegrich (2007:45-55) juga menyatakan bahwa implementasi kebijakan adalah bagian dari siklus proses kebijakan yang mencakupkan proses penetapan agenda, perumusan kebijakan dan pembuatan keputusan, implementasi, serta evaluasi dan terminasi.

Mengutip O'Toole, Jan dan Wegrich (2007:51-52), mendefinisikan implementasi kebijakan sebagai apa yang terjadi di antara penetapan intensi (maksud dan tujuan) pada pihak pemerintah untuk melakukan sesuatu, atau berhenti melakukan sesuatu, dan imbas akhirnya di dunia tindakan atau kenyataan. Sementara itu, Merilee S. Grindle, dalam Suharno (2008:190-191), menyatakan bahwa keberhasilan implementasi kebijakan dipengaruhi oleh dua variabel yaitu isi kebijakan (content of policy) dan lingkungan implementasi (context of implementation). Isi kebijakan yang dapat mempengaruhi keberhasilan implementasi kebijakan antara lain adalah kepentingan kelompok sasaran, jenis manfaat dari kebijakan yang akan diterima kelompok sasaran, perubahan yang diinginkan oleh kebijakan, kesesuaian institusi/implementer, dan dukungan sumber daya. Sedangkan konteks kebijakan yang dapat mempengaruhi keberhasilan pelaksanaan kebijakan meliputi: 1) seberapa besar kekuasaan, kepentingan, dan strategi yang dimiliki para aktor yang terlibat di dalam implementasi kebijakan, 2) karakteristik kelembagaan rejim yang berkuasa, dan 3) tingkat kepatuhan dan responsivitas kelompok sasaran. Mazmanian dan Sabatier, di dalam Hill dan Hupe (2002:7) menjelaskan, "implementation is the carrying out of a basic policy decision, usually incorporated in a statute but which can also take the form of important executive orders or court decisions. Ideally, that decision identifies the problem(s) to be addressed, stipulates the objective(s) to be pursued, and in a variety of ways, 'structures' the implementation process. The process normally runs through a number of stages beginning with passage of the basic statute, followed by the policy outputs (decisions) of the implementing agencies, the compliance of target groups with those decisions, the actual impacts - both intended and unintended - of those outputs, the perceived impacts of agency decisions, and finally, important revisions (or attempted revisions) in the basic statute".

Implementasi adalah pelaksanaan sebuah keputusan kebijakan dasar, biasanya dicantumkan di dalam statuta tapi dapat juga mengambil bentuk perintah dari eksekutif atau keputusan pengadilan. Idealnya, keputusan itu mengidentifikasi persoalan yang ingin ditangani, menetapkan sasaran yang ingin dicapai, dan dengan beragam cara, 'menstrukturkan' proses implementasi. Proses itu biasanya berjalan melalui sejumlah tahapan yang mulai dengan kalimat di dalam statuta, diikuti dengan output (keputusan) kebijakan tentang agen-agen pelaksana, kepatuhan kelompok-kelompok sasaran dengan keputusan itu, imbas aktual - yang dimaksudkan dan sampingan - dari output itu, imbas yang dibayangkan oleh keputusan agensi pelaksana, dan akhirnya, revisi (atau usaha revisi) yang penting terhadap statuta dasar.

Dari paparan di atas dapat disintesiskan bahwa implementasi kebijakan merupakan bagian dari proses atau siklus kebijakan dan menjadi tahap pelaksanaan 
untuk mencapai tujuan dari keputusan kebijakan dengan memperhatikan 1) isi kebijakan yang mencakup spesifikasi detail program kebijakan seperti kepentingan kelompok sasaran, jenis manfaat dari kebijakan yang akan diterima kelompok sasaran, perubahan yang diinginkan oleh kebijakan, kesesuaian institusi/implementer, dan dukungan sumber daya, 2) konteks kebijakan yang mencakup struktur birokrasi termasuk di dalamnya seberapa besar kekuasaan, kepentingan, dan strategi yang dimiliki para aktor yang terlibat di dalam implementasi kebijakan, karakteristik kelembagaan rejim yang berkuasa, tingkat kepatuhan dan responsivitas kelompok sasaran, dan 3) komunikasi dan disposisi para aktor kebijakan.

\section{Evaluasi}

Provus (1969:9) mengatakan bahwa "evaluation at its simplest level may be seen as the comparison of performance against a standard." Sementara itu Stufflebeam dkk, dalam Mehrens dan Lehmann (1991:4), mendefinisikan evaluasi sebagai "the process of delineating, obtaining, and providing useful information for judging decision alternatives," sedangkan Gronlund, dalam Djaali dan Muljono (2004:1), mengatakan bahwa evaluasi adalah suatu proses yang sistematis untuk menentukan atau membuat keputusan sampai sejauh mana tujuan atau program tercapai. Menurut Joy Frechtling dan Westat (2010:8-10),terdapat dua tipe evaluasi di dalam evaluasi formatif, yakni evaluasi implementasi dan evaluasi kemajuan. Evaluasi implementasi ditujukan untuk mengetahui dan menilai apakah program, proyek atau kebijakan dilaksanakan seperti yang direncanakan, sedangkan evaluasi kemajuan dimaksudkan untuk menilai kemajuan dalam pencapaian tujuan-tujuan khusus sebuah program, proyek atau kebijakan. Evaluasi sumatif, di sisi lainnya, adalah evaluasi yang dimaksudkan untuk menilai keberhasilan program, proyek atau kebijakan secara keseluruhan dalam mencapai tujuan-tujuan yang dinyatakan. Di dalam evaluasi ini, informasi yang dikumpulkan juga mencakup keluran dan proses yang saling terkait, strategi, dan kegiatan yang menghasilkan keluaran tersebut.

Dari pengertian-pengertian tentang evaluasi di atas dapat disintesiskan bahwa evaluasi pada dasarnya adalah sebuah proses pengumpulan data dan informasi yang bernilai dan diperlukan untuk menilai kinerja program atau kebijakan. Data dan informasi tersebut akan menjadi rujukan untuk menghasilkan keputusan bagi pembuat program, proyek, atau kebijakan guna merevisi, memodifikasi atau menghentikan program, proyek atau kebijakan tersebut.

\section{Evaluasi Implementasi Kebijakan}

Hellmut Wollmann (2007:393) mengatakan bahwa evaluasi di bidang kebijakan publik dapat didefinisikan "... in very general terms, as an analytical tool and procedure meant to do two things. First, evaluation research, as an analytical tool, involves investigating a policy program to obtain all information pertinent to the assessment of its performance, both process and result; second, evaluation as a phase of the policy cycle more generally refers to the reporting of such information back to the policy-making process." Sementara itu, Fretchling dan Westat (2010:8-10) mengatakan bahwa evaluasi implementasi ditujukan untuk mengetahui dan menilai apakah program, proyek atau kebijakan dilaksanakan seperti yang direncanakan, sebuah early check (pemeriksaan awal) oleh staf proyek/program untuk mengetahui apakah semua elemen yang esensial berada di tempatnya atau terpenuhi dan berjalan sesuai dengan rencana.

Dari paparan di atas dapat disintesiskan bahwa evaluasi implementasi kebijakan publik adalah evaluasi yang dilakukan pada satu bagian dari proses dan tahapan kebijakan publik yang dilakukan di sepanjang dan di seluruh tahap implementasi 
kebijakan untuk mengetahui dan menilai apakah program, proyek atau kebijakan dilaksanakan seperti yang direncanakan, apakah semua elemen yang esensial berada di tempatnya atau terpenuhi dan berjalan sesuai dengan rencana.

\section{Sarana dan Prasarana}

Menurut E. Mulyasa (2004:49) sarana pendidikan adalah peralatan dan perlengkapan yang secara langsung dipergunakan dan menunjang proses pendidikan, khususnya proses belajar mengajar seperti gedung, ruang kelas, meja kursi, serta alatalat dan media pengajaran. Adapun yang dimaksud dengan prasarana pendidikan adalah fasilitas yang secara tidak langsung menunjang jalannya proses pendidikan atau pengajaran, seperti halaman, kebun, taman sekolah, jalan menuju sekolah. Sementara itu, menurut Bafadal (2003:3), prasarana pendidikan adalah semua perangkat kelengkapan dasar yang secara tidak langsung menunjang pelaksanaan proses pendidikan di sekolah.

Land dan Hannafin (2000:3) mengatakan bahwa untuk pembelajaran di masa depan, lingkungan belajar sebaiknya dibangun di atas lima fondasi inti yaitu: psikologis, pedagogis, teknologis, kultur, dan pragmatis. Untuk mendorong pembelajaran, lingkungan belajar sebaiknya memperhatikan perbedaan gaya berpikir dan belajar pembelajar (psikologis) dengan cara bagaimana pelajaran disampaikan dan kegiatan dirancang untuk menstimuli pembelajar (pedagogis). Pilihan terhadap kandungan pelajaran yang ingin disampaikan dan bagaimana hal itu disampaikan dapat sangat dipengaruhi oleh ketersediaan sumber daya (teknologis). Pada gilirannya, pilihan metode dan materi pelajaran dipengaruhi oleh nilai-nilai utama yang dianut oleh komunitas pembelajar dan, akhirnya, fondasi pragmatis menekankan rekonsiliasi sumber daya yang tersedia dan hambatan dengan disain actual lingkungan belajar tertentu.

Gregori dalam (http://mcgraw-hillresearchfoundation.org/wpcontent/uploads/ 2011/10/Reimagining the_Classroom_DeGre- goriFINAL.pdf) menyatakan bahwa dalam pembelajaran saat ini yang diperlukan adalah lingkungan fisik yang "... is not treated simply as a background setting within which teaching and learning occur, but as an active variable that supports and enhances both" Ttidak diperlakukan sekadar sebagai latar belakang yang di dalamnya pengajaran dan pembelajaran berlangsung, tapi sebagai variable aktif yang mendukung dan memperkuat keduanya), karena kemajuan teknologi telah membawa perubahan pada cara siswa belajar dan teori pembelajaran konstruktivis menganjurkan perubahan dari mode pembelajaran tradisional (berpusat-guru) ke pembelajaran yang lebih bersifat kooperatif, kolaboratif, elaboratif.

Dari paparan di atas dapat disintesiskan bahwa sarana dan prasarana sekolah adalah bagian dari lingkungan belajar yang lebih luas yang didalamnya kegiatan mengajar dan belajar berlangsung. Sarana sekolah meliputi semua peralatan dan perlengkapan yang berhubungan langsung dengan kegiatan pembelajaran, sementara prasarana sekolah mencakup seumua perangkat kelengkapan dasar yang secara tidak langsung menunjang pelaksanaan proses pendidikan di sekolah. Oleh karena itu, sarana dan prasarana sekolah harus dibangun dengan memperhatikan prinsip psikologis, pedagogis, teknologis, kultur, dan pragmatis untuk mengakomodasi dan mengantisipasi kebutuhan dan perkembangan kegiatan pembelajaran saat ini dan di masa depan. 


\section{Laboratorium Fisika}

Hofstein dan Luneta mendefinisikan kegiatan-kegiatan laboratorium Fisika sebagai pengalaman belajar di mana siswa berinteraksi dengan bahan dan/atau kegiatan untuk mengamati dan memahami fenomena alam. Butin, et al., (2011) mengatakan bahwa National Research Council's National Science Education Standards meminta pendidikan sains "developmentally appropriate, interesting, and relevant to students' lives, emphasizing student understanding through inquiry, and be connected with other school subjects."

Gorey (http://www.oecd. org/dataoecd/41/3/2032085.pdf.) menjelaskan laboratorium sains di sekolah diciptakan untuk memberikan hasil terbaik pada hasil belajar siswa. Saat merencanakan laboratorium sains sekolah, perencana dan perancang harus memerhatikan implikasi kependidikan dan struktural jangka-panjang. Untuk itu, mereka harus memerhatikan dengan cermat kesinambungan kependidikan, lingkungan, dan fisik disain mereka. membangun laboratorium Fisika yang berkualitas dan memerhatikan prinsip-prinsip di atas akan menjadi tantangan yang sangat besar. Piggott (2011:5) menyebutkan bahwa keinginan untuk membangun fasilitas sains yang bermutu tinggi kerap terhalangi karena kurangnya pengetahuan tentang rupa atau wajah fasilitas sains itu sendiri, fleksibilitas untuk menciptakan ukuran optimum dan bentuk ruang-ruang laboratorium di dalam bangunan sekolah, anggaran, dan pengetahuan tentang hal-hal dasar yang diperlukan untuk kesehatan dan keselamatan. Membangun laboratorium Fisika yang berkualitas dan memerhatikan prinsip-prinsip di atas akan menjadi tantangan yang sangat besar.

Dari paparan di atas dapat disintesiskan bahwa laboratorium Fisika adalah sarana dan prasarana di sekolah untuk memberikan pengalaman mengamati, mengidentifikasi, membuat hipotesis, menyimpulkan dan merekonstruksi objek atau fenomena alam. Bangunan ruang laboratorium Fisika dibuat dengan memperhatikan perkembangan siswa, relevan bagi kehidupan siswa, dan menekankan pemahaman siswa melalui inkuiri, serta dikaitkan dengan pelajaran-pelajaran sekolah lainnya. 


\section{METODE PENELITIAN}

Penelitian ini menggunakan metode evaluasi implementasi kebijakan. Penelitian dilakukan di SMAN 2 Kota Tangerang Selatan. Discrepancy evaluation model yang dikembangkan Provus digunakan untuk mengevaluasi implementasi kebijakan standar sarana dan prasarana. Dengan model ini, aspek penerapan persyaratan dan ketentuan bangunan laboratorium dan aspek pemenuhan jenis dan jumlah perabot dan peralatan laboratorium Fisika dievaluasi pada komponen input, proses, dan output berdasarkan kriteria evaluasi. Kriteria evaluasi pada aspek penerapan persyaratan dan ketentuan bangunan laboratorium adalah keselamatan, kesehatan, kenyamanan, kemudahan dan aksesibilitas, dan ukuran dan kelengkapan ruang laboratorium. Kriteria evaluasi pada aspek pemenuhan jenis dan jumlah perabot dan peralatan laboratorium Fisika adalah jenis dan jumlah perabot laboratorium dan jenis dan jumlah peralatan laboratorium.

Data yang dikumpulkan dalam penelitian ini mencakup data kuantitatif dan kualitatif. Data kualitatif diperoleh melalui wawancara dengan responden yang terdiri dari Kepala Sekolah, Wakil Kepala Sekolah bidang sarana dan prasarana, 4 (empat) guru mata pelajaran Fisika, dan 9 (sembilan) murid Kelas X, XI, dan XII jurusan IPA di SMAN 2 Kota Tangerang Selatan. Selain wawancara, studi dokumen yang relevan juga dilakukan untuk mendapatkan data kualitatif. Data kuantitatif diperoleh melalui lembar observasi untuk mengukur kesesuaian penerapan persyaratan dan ketentuan bangunan serta pemenuhan jenis dan jumlah perabot dan peralatan laboratorium Fisika.

Data yang dikumpulkan direduksi dengan memilah, menggolongkan atau melakukan kategorisasi, membuang yang tidak perlu dan mengorganisasi data sehingga kesimpulan-kesimpulan dapat ditarik dan diverifikasi. Kemudian, data hasil resukdis disajikan dalam bentuk tabel untuk memudahkan data dipahami.

\section{HASIL PENELITIAN}

Aspek Penerapan Persyaratan dan Ketentuan Bangunan Laboratorium Fisika SMAN 2 Kota Tangerang Selatan

\section{Keselamatan}

Dengan membandingkan kesesuaian disain bangunan (komponen input) dengan standar di indikator struktur bangunan kukuh dan stabil dan indikator sistem proteksi aktif dan pasif, diketahui bahwa disain bangunan laboratorium menerapkan 55,56\% persyaratan dan ketentuan keselamatan. Kemudian, dengan membandingkan kesesuaian proses pembangunan (komponen proses) dengan disain bangunan laboratorium di kedua indikator tersebut, diketahui bahwa proses pembangunan memiliki kesesuaian $77,8 \%$ dari disain. Selanjutnya, dengan membandingkan kesesuaian bangunan laboratorium (komponen output) dengan standar di kedua indikator tersebut, diketahui bahwa bangunan laboratorium menerapkan 88,9\% persyaratan dan ketentuan keselamatan.

\section{Kesehatan}

Dengan membandingkan kesesuaian disain bangunan (komponen input) dengan standar di indikator fasilitas pencahayaan dan udara, indikator fasilitas sanitasi dan pengolahan limbah, dan indikator penggunaan bahan bangunan yang aman bagi kesehatan dan tidak berdampak negatif pada lingkungan, diketahui bahwa disain bangunan laboratorium menerapkan $18,2 \%$ persyaratan dan ketentuan kesehatan. Kemudian, dengan membandingkan kesesuaian proses pembangunan (komponen 
proses) dengan disain bangunan laboratorium di ketiga indikator tersebut, diketahui bahwa proses pembangunan memiliki kesesuaian 36,4\% dari disain. Selanjutnya, dengan membandingkan kesesuaian bangunan laboratorium (komponen output) dengan standar di ketiga indikator tersebut, diketahui bahwa bangunan laboratorium menerapkan $72.7 \%$ persyaratan dan ketentuan kesehatan.

Kenyamanan

Dengan membandingkan kesesuaian disain bangunan (komponen input) dengan standar di indikator tata letak perabot, indikator rasio luas ruang laboratorium terhadap jumlah siswa, indikator kelembaban udara di dalam laboratorium, dan indikator kebisingan di sekitar laboratorium, diketahui bahwa disain bangunan laboratorium menerapkan 33,34\% persyaratan dan ketentuan kenyamanan. Kemudian, dengan membandingkan kesesuaian proses pembangunan (komponen proses) dengan disain bangunan laboratorium di keempat indikator tersebut, diketahui bahwa proses pembangunan memiliki kesesuaian $36,4 \%$ dari disain. Selanjutnya, dengan membandingkan kesesuaian bangunan laboratorium (komponen output) dengan standar di keempat indikator tersebut, diketahui bahwa bangunan laboratorium menerapkan $36,4 \%$ persyaratan dan ketentuan kenyamanan.

Kemudahan dan Aksesibilitas

Dengan membandingkan kesesuaian disain bangunan (komponen input) dengan standar di indikator pintu laboratorium, indikator tangga akses ke laboratorium, indikator ramp laboratorium, indikator petunjuk arah ke laboratorium, dan indikator nama ruang laboratorium pada kriteria kemudahan dan aksesibilitas, diketahui bahwa disain bangunan laboratorium menerapkan 21,05\% persyaratan dan ketentuan kemudahan dan aksesibilitas. Kemudian, dengan membandingkan kesesuaian proses pembangunan (komponen proses) dengan disain bangunan laboratorium di kelima indikator tersebut, diketahui bahwa proses pembangunan memiliki kesesuaian 47,37\% dari disain. Selanjutnya, dengan membandingkan kesesuaian bangunan laboratorium (komponen output) dengan standar di kelima indikator tersebut, diketahui bahwa bangunan laboratorium menerapkan $52,63 \%$ persyaratan dan ketentuan kemudahan dan aksesibilitas.

\section{Ukuran dan Kelengkapan Ruang}

Dengan membandingkan kesesuaian disain bangunan (komponen input) dengan standar di indikator ukuran ruang laboratorium dan indikator kelengkapan ruang laboratorium, diketahui bahwa disain bangunan laboratorium menerapkan 33,33\% persyaratan dan ketentuan ukuran dan kelengkapan ruang laboratorium Fisika. Kemudian, dengan membandingkan kesesuaian proses pembangunan (komponen proses) dengan disain bangunan laboratorium di kedua indikator tersebut, diketahui bahwa proses pembangunan memiliki kesesuaian $44,44 \%$ dari disain. Selanjutnya, dengan membandingkan kesesuaian bangunan laboratorium (komponen output) dengan standar di kedua indikator tersebut, diketahui bahwa bangunan laboratorium menerapkan 55,56\% persyaratan dan ketentuan ukuran dan kelengkapan ruang laboratorium Fisika. 
Aspek Pemenuhan Jenis dan Jumlah Perabot dan Peralatan Laboratorium Fisika SMAN 2 Kota Tangerang Selatan

\section{Jenis dan Jumlah Perabot Laboratorium Fisika SMAN 2 Kota Tangerang Selatan}

Dengan membandingkan kesesuaian Rencana Anggaran Belanja (RAB) bangunan (komponen input) dengan standar di indikator jenis dan jumlah perabot laboratorium, diketahui bahwa disain bangunan laboratorium menerapkan $85,7 \%$ persyaratan dan ketentuan jenis dan jumlah perabot laboratorium Fisika. Kemudian, dengan membandingkan kesesuaian proses pemenuhan perabot (komponen proses) dengan RAB bangunan laboratorium, diketahui bahwa SMAN 2 Kota Tangerang Selatan memenuhi $85,7 \%$ jenis dan jumlah perabot yang terdapat pada RAB. Selanjutnya, dengan membandingkan kesesuaian jenis dan jumlah perabot laboratorium (komponen output) dengan standar, diketahui bahwa laboratorium SMAN 2 Kota Tangerang Selatan memenuhi $85,7 \%$ persyaratan dan ketentuan jenis dan jumlah perabot laboratorium Fisika.

\section{Jenis dan Jumlah Peralatan Laboratorium Fisika SMAN 2 Kota Tangerang Selatan}

Pada komponen input, jenis dan jumlah peralatan laboratorium Fisika SMAN 2 Kota Tangerang Selatan terpenuhi 100\% karena pemenuhannya didapat dari Departemen Pendidikan dan Kebudayaan. Pada komponen proses, pemenuhan jenis dan jumlah peralatan laboratorium tidak dapat dibandingkan dan dievaluasi karena dokumen serah terima peralatan dari Depdikbud ke sekolah tidak tersedia untuk dijadikan acuan evaluasi. Selanjutnya, dengan membandingkan kesesuaian jenis dan jumlah peralatan laboratorium (komponen output) dengan standar, diketahui bahwa laboratorium SMAN 2 Kota Tangerang Selatan memenuhi 70,7\% persyaratan dan ketentuan jenis dan jumlah peralatan laboratorium Fisika.

\section{KESIMPULAN DAN REKOMENDASI}

Kesimpulan: Berdasarkan hasil evaluasi dapat disimpulkan bahwa: 1) pada komponen input, SMAN 2 Kota Tangerang Selatan tidak menerapkan semua persyaratan dan ketentuan bangunan dan tidak memenuhi semua jenis dan jumlah perabot dan peralatan laboratorium Fisika, 2) pada komponen proses, pembangunan laboratorium Fisika SMAN 2 Kota Tangerang Selatan tidak mengikuti semua bagian yang terdapat di dalam disain bangunan dan tidak semua jenis dan jumlah perabot dan peralatan laboratorium terpenuhi sesuai $\mathrm{RAB}$, dan 3) pada komponen output, bangunan laboratorium tidak menerapkan semua persyaratan dan ketentuan bangunan dan tidak semua jenis dan jumlah perabot dan peralatan laboratorium Fisika terpenuhi.

Rekomendasi: Penelitian ini merekomendasikan: 1) SMAN 2 Kota Tangerang Selatan perlu melengkapi kekurangan yang terdapat pada bangunan laboratorium Fisika agar sesuai dengan persyaratan dan ketentuan bangunan laboratorium Fisika. Hal yang perlu dilengkapi di sini adalah penyediaan penangkal petir (kriteria keselamatan), penyediaan exhaust fan, menyediakan air bersih agar fasilitas sanitasi berfungsi semestinya, menambah jumlah titik lampu di ruang praktikum, menyesuaikan jumlah dan jenis peruntukan tempat sampah (kriteria kesehatan), mendisain ulang tata letak perabot (meja dan kursi praktikum) (kriteria kenyamanan), mengubah arah bukaan pintu ruang laboratorium, ruang persiapan, dan ruang gelap dan memperbaiki tangga (kriteria kemudahan dan aksesibilitas), dan melengkapi ruang persiapan dengan wastafel serta menyesuaikan jumlah stop kontak listrik (kriteria ukuran dan kelengkapan ruang), dan 2) SMAN 2 Kota Tangerang Selatan perlu membuat 
perencanaan yang rinci terkait jenis dan jumlah peralatan laboratorium Fisika sesuai fungsi peralatan tersebut (alat ukur dasar, alat percobaan, media pendidikan, dan perlengkapan lain).

\section{DAFTAR REFEREMSI}

Bafadal, Ibrahim. Seri Manajemen Peningkatan Mutu Pendidikan Berbasis Sekolah, Manajemen Perlengkapan Sekolah: Teori dan Aplikasi. Cet I. Jakarta: PT Bumi Aksara, 2003.

Butin, Dan W., et. al. Science Facilities, http://www.ncef.org/pubs/science.pdf Diakses pada 20 Juni 2011.

Frechtling, Joy., Westat. The 2010 User Friendly Handbook for Project Evaluation. Virginia: National Science Foundation, 2002.

Gorey, Ann. School Science Laboratories: Planning for Sustainability. http://www.oecd.org/dataoecd/41/3/2032085.pdf. Diakses pada 20 Juni 2011

Hadad, Wadi D. Education Policy-Planning Process: An Applied Framework. Paris: Unesco, 1995.

Hill, Michael. Hupe, Peter. Implementing Public Policy: Governance in Theory and in Practice. London: Sage Publication, 2002.

Hofstein, Avi. Lunetta, Vincent N. "The laboratory in Science Education: Foundations for the Twenty-First Century", Sci Ed 88.

Jann, Warner, Wegrich, Kai. "Theories of the Policy Cycle" dalam Fischer, Frank. Miller, Gerald J. Sidney, Mara S. (eds). Handbook of Public Policy Analysis, Theory, Practice, and Methods. Florida: CRC Press, 2007.

Mehrens, William A. Lehmann, Irvin J. Measurement and Evaluation in Education and Psychology. Belmont: Wadsworth/Thompson Learning, 1991.

Mulyasa, E. Manajemen Berbasis Sekolah. Cet. VII. Bandung: PT Remaja Rosdakarya, 2004.

Mustopadidjaja. Manajemen Proses Kebijakan Publik. Jakarta: Lembaga Administrasi Negara, 2002.

Peraturan Pemerintah Nomor 19 Tahun 2005.

Piggott, Andy. Science Labs in Secondary Schools: A Special Report to Good Science Lab Standards for Architects and Designers. Essex: Gratnells, 2011.

Provus, Malcolm M. The Discrepancy Evaluation Model: An Approach to Local Program Improvement and Development. Diunduh dari ERIC Database (EDO30957). 12 September 2014. 
Suharno. Dasar-dasar Kebijakan Publik: Kajian Proses dan Analisis Kebijakan. Yogyakarta: UNY Press, 2008.

Undang-undang Sisdiknas No. 20 Tahun 2003.

Wollmann, Hellmut. "Policy Evaluation and Evaluation Research" dalam Fischer, Frank. Miller, Gerald J. Sidney, Mara S. (eds). Handbook of Public Policy Analysis, Theory, Practice, and Methods. Florida: CRC Press, 2007 